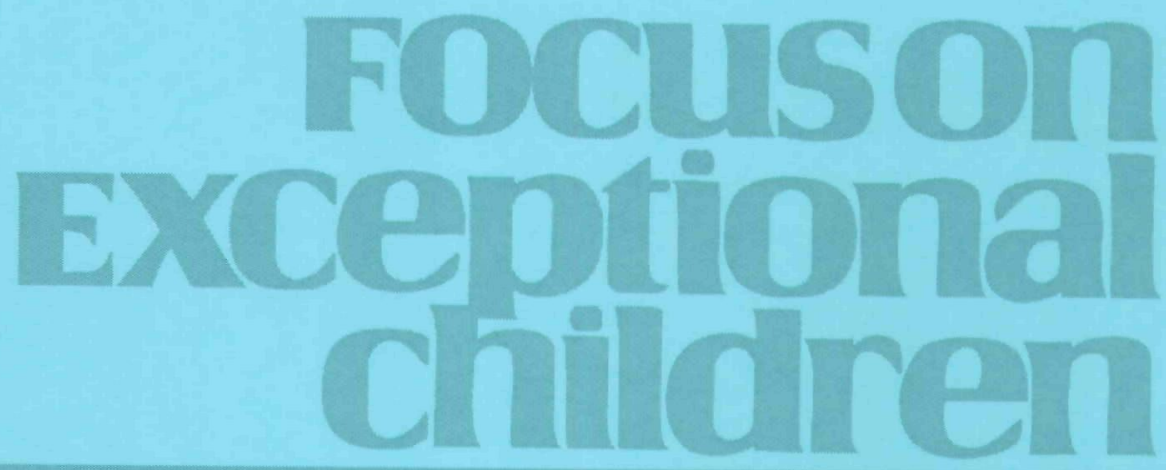

\title{
Sustainable Change in Quality of Life for Individuals with ASD: Using a Comprehensive Planning Process
}

\author{
Sheila M. Smith, Brenda Smith Myles, Ruth Aspy, Barry G. Grossman, \\ and Shawn A. Henry
}

In 2009, two reports were published on the prevalence of autism spectrum disorders (ASD). One identified the prevalence of ASD as being 1 in 110 (Centers for Disease Control and Prevention, 2009), and the other cited a prevalence rate of 1 in 91 (Kogan et al., 2009). At approximately the same time, three published reports attempted to identify evidence-based practice for children and youth on the spectrum.

In order to determine whether studies on interventions were scientifically rigorous, the first report, from the National Professional Development Center on ASD (NPDC on ASD, 2009), used the following criteria for articles on interventions used with individuals with ASD (excluding intervention packages): They cite (a) at least two experimental or quasiexperimental group design studies carried out by independent investigators, (b) at least five single-case design studies from at least three independent investigators, or (c) a combination of at least one experimental/quasi-experimental study and three single-case design studies from independent investigators.

The authors of the second report (National Autism Center [NAC], 2009) developed a Scientific Merit Rating Scale (SMRS) that analyzed within an article (a) research design, (b) measurement of the dependent variable, (c) measurement of the independent variable or procedural fidelity, (d) participant ascertainment, and (e) generalization. Each of these elements was subsequently rated on a 5 -point Likert scale with scores of 3,4 , or 5 indicating scientific rigor.

The third report, commissioned by the Centers for Medicare and Medicaid Services (CMS, 2010), sought to determine scientific evidence of the efficacy, effectiveness, safety, and availability of ASD-related psychosocial services and supports for children, transitioning youth, and adults with ASD. Articles on interventions were classified as evidencebased using the criteria adopted by the NPDC on ASD and the categories identified by the NAC.

Table 1 lists interventions identified as effective in the above reports. Because one of the three documents used different intervention terminology and descriptions, we have categorized the three lists using verbiage from each report so that the reader can determine the level of overlap among the reports.

Dr. Smith is an assistant director at the Ohio Center for Autism and Low Incidence (OCALI). Dr. Myles is an independent consultant with the Autism Society. Dr. Aspy and Dr. Grossman are psychologists with the Ziggurat Group, and Mr. Henry is the executive director at OCALI. 
We now have an understanding of evidence-based practices in isolation. The next step is to determine whether a particular intervention or, more likely, sets of interventions matches a learner's strengths and needs. To do so, we must begin with a thorough understanding of the student's needs, especially those related to the underlying characteristics of ASD. Next comes the process of identifying long- and shortterm goals for the learner, which in turn will help in selecting the most appropriate instructional strategies. The next critical step consists of integrating these strategies systematically and comprehensively throughout the student's day by developing a comprehensive daily schedule for the student. Such a schedule should embed the supports needed for success and provide continual development of student skills and measurement of those skills with a vision of the effect on the student now and in the future (National Research Council [NRC], 2001).

To maximize educational benefit, "evidence-based practices must be carefully selected to meet student needs AND

\section{FOCuson Exceptional children}

ISSN 0015-511X

FOCUS ON EXCEPTIONAL CHILDREN (USPS 203-360) is published monthly except June, July, and August as a service to teachers, special educators, curriculum specialists, administrators, and those concerned with the special education of exceptional children. This publication is annotated and indexed by the ERIC Clearinghouse on Handicapped and Gifted Children for publication in the monthly Current Index to Journals in Education (CIJE) and the quarterly index, Exceptional Children Education Resources (ECER). The full text of Focus on Exceptional Children is also available in the electronic versions of the Education Index. It is also available in microfilm from Serials Acquisitions, National Archive Publishing Company, P.O. Box 998, Ann Arbor, MI 48106-0998. Subscription rates: individual, \$48 per year; institutions, \$66 per year. Copyright (1) 2010, Love Publishing Company. All rights reserved. Reproduction in whole or part without written permission is prohibited. Printed in the United States of America. Periodical postage is paid at Denver, Colorado. POSTMASTER: Send address changes to:

Love Publishing Company

Executive and Editorial Office P.O. Box 22353

Denver, Colorado 80222

Telephone (303) 221-7333

\section{CONSULTING EDITORS}

Steve Graham Vanderbilt University
Ron Nelson

University of Nebraska-Lincoln

Eva Horn

University of Kansas

Carrie E. Watterson Senior Editor
Stanley F. Love Publisher they must be implemented well" (Fixsen, Blasé, Horner, \& Sugai, 2009, p. 5, emphasis in original) in all educational settings. This type of comprehensive implementation usually requires changes in the daily activities of staff, related service providers, administrators, and even parents. Thus, it takes cohesive team planning, clearly defined objectives, and professional development of all personnel to ensure that the chosen evidence-based strategies are implemented with fidelity and across all settings.

To date, no single system has been able to accomplish these lofty goals. This article introduces two linked comprehensive planning models - the Ziggurat Model (Aspy \& Grossman, 2007) and the Comprehensive Autism Planning System (CAPS; Henry \& Myles, 2007) - that together meet these goals. Figure 1 depicts the process of comprehensive planning using the Ziggurat Model and CAPS.

\section{WHAT IS THE ZIGGURAT MODEL?}

The Ziggurat Model is a comprehensive planning model for individuals with ASD based on the premise that, in order for a program to be successful for individuals with ASD, their unique needs and strengths must be identified and then directly linked to interventions (Aspy \& Grossman, 2007). Therefore, the Ziggurat Model utilizes students' strengths to address true needs or underlying deficits that result in social, emotional, and behavioral concerns. In doing so, the Ziggurat approach centers on a hierarchical system consisting of five levels: sensory differences and biological needs, reinforcement, structure and visual/tactile supports, task demands, and skills to teach that must be addressed for an intervention plan to be comprehensive (see Figure 2). The model can be used in two ways: (a) as a global planning tool for school, home, workplace, and/or community; or (b) as a functional behavior assessment.

When designing a comprehensive program, it is essential to consider the context of the underlying autism spectrum disorder. Unfortunately, this is overlooked all too often. Traditional views of program planning often focus on interventions that address only surface or observable behavior without consideration of underlying ASD characteristics. Such approaches are potentially less effective and, therefore, less likely to result in sustained behavior change. The Ziggurat Model's approach is different. It targets an individual's specific needs, defined by ASD characteristics. This leads to interventions that are proactive and effective. The following example illustrates the difference between an educational program that is designed using surface behaviors as an impetus and a program based on an individual's underlying autism.

Rick's transdisciplinary team, including his parents, wanted to develop a program to increase his interaction with 


\section{TABLE 1 \\ Evidence-Based Practices (EBP)}

\begin{tabular}{ll} 
Intervention & $\begin{array}{l}\text { Centers for Medicare and } \\
\text { Medicaid Services (CMS) }\end{array}$ \\
\hline
\end{tabular}

Antecedent Package

\section{(0-16) (17-21)}

Modifications of events that typically precede the occurrence of a target behavior. These alterations are made to increase the likelihood of success or reduce the likelihood of problems.
Behavioral

Package
(0-16)

Interventions designed to reduce problem behavior and teach functional alternative behaviors or skills through the application of basic principles of behavior change.
Differential

Reinforcement

\section{Extinction}

Prompting

Reinforcement

\section{National Professional Development Center on ASD (NPDC)}

(3-18)

Behavior chain interruption; behavioral momentum; choice; cueing/prompting; environmental enrichment/modification; errorless learning; habit reversal; incorporating echolalia, special interests, thematic activities, or ritualistic obsessional activities; maintenance interspersal; noncontingent access/reinforcement; priming; stimulus variation; time delay.

\section{$(0-21)$}

Sleep package; toilet training; chaining; contingency contracting; contingency mapping; delayed contingencies; DR strategies; DTT; FCT; generalization training; mand training; noncontingent escape with fading; progressive relaxation; reinforcement; scheduled awakenings; shaping; stimulus-stimulus pairing with reinforcement; successive approximation; task analysis; token economy.

\section{Antecedent-Based Interventions} (EC-MH)

Include (a) using highly preferred activities/items to increase interest level, (b) changing schedule/ routine, (c) implementing preactivity interventions, (d) offering choices, (e) altering the manner in which instruction is provided, and (f) enriching the environment for access to sensory stimuli that serve the same function as the interfering behavior.
(EC-H)

Reinforcement is provided for desired behaviors, while inappropriate behaviors are ignored.

\section{(EC-MH)}

Based on applied behavior analysis, is used to reduce or eliminate unwanted behavior. Extinction involves withdrawing or terminating the positive reinforcer that maintains an inappropriate interfering behavior.

(EC-MH)

Any help given to learners that assists them in using a specific skill.

\section{(EC-MH)}

A relationship between learner behavior and a consequence that follows the behavior. This relationship is considered reinforcement only if the consequence increases the probability that a behavior will occur in the future or at least be maintained. 


\section{TABLE 1 (Cont.)}

\begin{tabular}{llll}
\hline Intervention & (CMS) & (NAC) \\
\hline Time Delay & & (NP)
\end{tabular}

Time Delay
Cognitive

Behavioral

Intervention

Package

Comprehensive

Behavioral

Treatment for

Children

Discrete Trial

Training

Functional

Behavior

Assessment

Joint Attention

Intervention

Modeling
(0-16)

Interventions designed to change negative or unrealistic thought patterns/behaviors to positively influencing emotions/life functioning.

\section{(0-16)}

Interventions involving a combination of instructional and behavior change strategies and a curriculum that addresses core and ancillary symptoms and behaviors of ASD.
(0-8)

Using ABA strategies (e.g., DTT, incidental teaching, errorless learning, behavioral momentum, and shaping). Criteria: (a) defined ASD symptoms, (b) treatment manuals, (c) intensive treatment, and (d) measuring program effectiveness.
(EC, E)

DTT is a one-to-one instructional approach. Used when a learner needs to learn a skill best taught in small, repeated steps. Each trial or teaching opportunity has a definite beginning and end. The use of antecedents and consequences is carefully planned and implemented.

(EC-MH)

Systematic strategies used to determine underlying behavior function or purpose, so that an effective intervention plan can be developed.

$(0-5)$

(0-16)

Interventions involving teaching a child to respond to the nonverbal social bids of others or to initiate joint attention interactions.

(0-16)

Interventions relying on an adult or peer providing a demonstration of the target behavior that should result in an imitation by the person with ASD.
(E) tional activities. With this procebetween the initial instruction and any additional instructions or prompts. the use of prompts during instruc-
Often taught in a DTT format; examples include pointing, showing items/activities to another person, and following eye gaze.

\section{(3-18)}

Examples include live modeling and video modeling.
See Video Modeling 
TABLE 1 (Cont.)

\begin{tabular}{llll}
\hline Intervention & (CMS) & (NAC) & (NPDC) \\
\hline
\end{tabular}

\section{Multi- \\ Component \\ Package}

\begin{abstract}
Naturalistic
Teaching
\end{abstract}

Strategies

Peer Training

Package

Parent

Implemented

Interventions

\section{$(0-16)$}

These interventions involve a combination of multiple treatment procedures that are derived from different fields of interest or different theoretical orientations. They do not better fit one of the other treatment "packages" in this list nor are they associated with specific programs.

\section{(0-16) (0-9)}

Primarily child-directed interactions to teach functional skills in the natural environment: providing a stimulating environment, modeling how to play, encouraging conversation, providing choices and direct/natural reinforcers, and rewarding reasonable attempts.
Different names include focused stimulation, incidental teaching, milieu teaching, embedded teaching, and responsive education and prelinguistic milieu teaching.
$(0-16)$

These interventions involve teaching children without disabilities strategies to facilitate play and social interactions with children on the autism spectrum. Peers often include classmates or siblings.

\section{Picture}

Exchange

Communication

System (PECS)

\section{Pivotal}

Response

Treatment
$(0-16)$

Involves the application of a specific augmentative and alternative communication (AAC) system based on behavioral principles that are designed to teach functional communication to children with limited verbal and/or communication skills.

\section{(0-16)}

Focuses on targeting "pivotal" behavioral areas such as motivation to engage in social communication, self-initiation, self-management, and responsiveness to multiple cues.

\section{(3-14)}

There are many different peer training programs, including Project LEAP, peer networks, circle of friends, buddy skills package, Integrated Play Groups, peer initiation training, and peer-mediated social interaction training.

\section{(3-9)}

This treatment is an expansion of Natural Language Paradigm.

\section{(EC-MH)}

Includes environmental arrangement, interaction techniques, and behavioral strategies designed to encourage specific target behaviors. Builds more elaborate learner behaviors that are naturally reinforcing and appropriate to the interaction.

\section{(EC-E)}

Parent-implemented intervention entails parents directly using individualized intervention practices with their child to increase positive learning opportunities and acquisition of important skills.

\section{(EC-MH)}

\section{Peer-Mediated Instruction/} Intervention

Peers are systematically taught ways of engaging learners with ASD in social interactions in both teacher-directed and learner-initiated activities

\section{(EC-E)}

Learners are taught to give a picture of a desired item to a communicative partner in exchange for the item.

\section{(EC-MH)}

\section{Pivotal Response Training}

Creates a more efficient and effective intervention by enhancing four pivotal variables: motivation, responding to multiple cues, selfmanagement, and self-initiations. 


\section{TABLE 1 (Cont.)}

\begin{tabular}{lll}
\hline Intervention $(C M S)$ & (NAC) & (NPD) \\
\hline Response & RIR contains two main compo- \\
Interruption & nents: During the response inter- \\
and & ruption component, practitioners \\
Redirection & stop the learner from engaging in \\
(RIR) & the interfering behavior. Redirection \\
& focuses on prompting the learner \\
& to engage in a more appropriate, \\
& alternative behavior.
\end{tabular}

Self-

Management

Social Skills

Groups

Social Skills

Package

Story-Based

Intervention

Package

Social

Narratives
(0-16)

These interventions teach individuals with ASD to regulate their behavior by recording the occurrence/nonoccurrence of the target behavior and securing reinforcement for doing so.

\section{(0-16)}

These psychosocial interventions involve targeting some combination impairments such as pragmatic communication skills and the inability to successfully read social situations.

\section{(3-18)}

These interventions promote independence by teaching individuals with ASD to regulate their behavior by recording the target behavior and securing reinforcement for doing so.

\section{(EC-MH)}

Learners with ASD are taught to discriminate between appropriate and inappropriate behaviors, monitor and record their own behaviors, and reward themselves.
(EC-MH)

Social skills groups typically involve small groups of two to eight individuals with disabilities and a teacher or adult facilitator. Most social skill group meetings include instruction, role-playing or practice, and feedback.
$(0-16)$

These interventions seek to build social interaction skills by targeting basic responses to complex social skills.

$$
\text { (0-16) }
$$

These treatments involve a written description of the situations under which specific behaviors are expected to occur. Stories may be supplemented with additional components.
(6-14)

Social Stories ${ }^{\mathrm{TM}}$ are the best known story-based interventions. They seek to answer the "who," "what," "when," "where," and "why" in order to improve perspective-taking.
(EC-MH)

Social narratives describe social situations in some detail by highlighting relevant cues and offering examples of appropriate responding. 
TABLE 1 (Cont.)

\begin{tabular}{ll}
\hline Intervention & (CMS) \\
\hline $\begin{array}{l}\text { Speech } \\
\text { Generating } \\
\text { Devices (SGD) }\end{array}$ & \\
& \\
Structured & $\begin{array}{l}\text { (0-16) } \\
\text { Teaching }\end{array}$ \\
$\begin{array}{l}\text { This intervention involves a combi- } \\
\text { nation of procedures that rely on } \\
\text { the physical organization of a set- } \\
\text { ting, predictable schedules, and } \\
\text { individualized use of teaching } \\
\text { methods. These treatment pro- } \\
\text { grams may also be referred to as } \\
\text { TEACCH. }\end{array}$
\end{tabular}

\section{(NAC)}

(NPDC)

(EC-MH)

SGD are electronic devices that are portable and can produce either synthetic or digital speech for the user. SGD may be used with graphic symbols, as well as with alphabet keys.

\section{(EC-MH)}

Structured Work Systems

The individual work system is defined as a visually organized space where learners independently practice skills that have been previously mastered under the direct supervision of an adult.

Task Analysis

(EC-MH)

Breaking a skill into smaller, more manageable steps to teach the skill.

Technology-

Based

Treatment

Computer-

Aided

Instruction

\section{Video}

Modeling

Visual

Supports

\section{Schedules}

\section{$(0-16)$}

The presentation of instructional materials using the medium of computers or related technologies.

\section{(E-MH)}

A mode of teaching that uses video recording and display equipment to provide a visual model.

\section{(EC-MH)}

Any tool presented visually that supports an individual as he moves through the day.

\section{(0-16)}

Interventions involving the presentation of a task that communicates a series of activities or steps required to complete a specific activity.
(3-14)

These interventions involve the presentation of a task list that communicates a series of activities or steps required to complete a specific activity.

\section{(E-MH)}

Use of computers to teach academic skills and to promote communication and language development and skills. It includes computer modeling and computer tutors. 


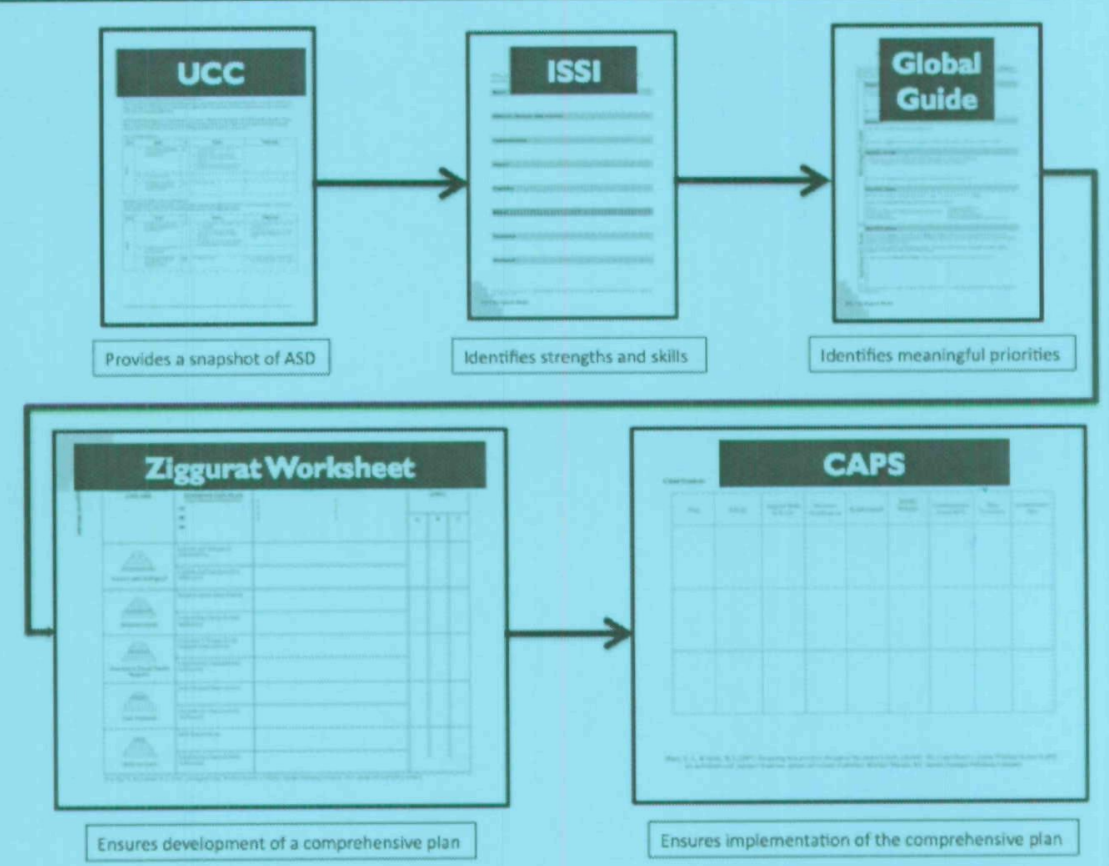

Source: From The Process of Comprehensive Planning Using the Ziggurat Model and the Comprehensive Autism Planning Systems (CAPS), by B. G. Grossman \& R. Aspy, 2010. Retrieved from http://www.aapctextbooks.net/textbook_9502_ziggu rat_textbook_features.htm. Copyright 2010 by B. G. Grossman \& R. Aspy. Reprinted with permission.

FIGURE 1. Process of Comprehensive Planning Using the Ziggurat and CAPS

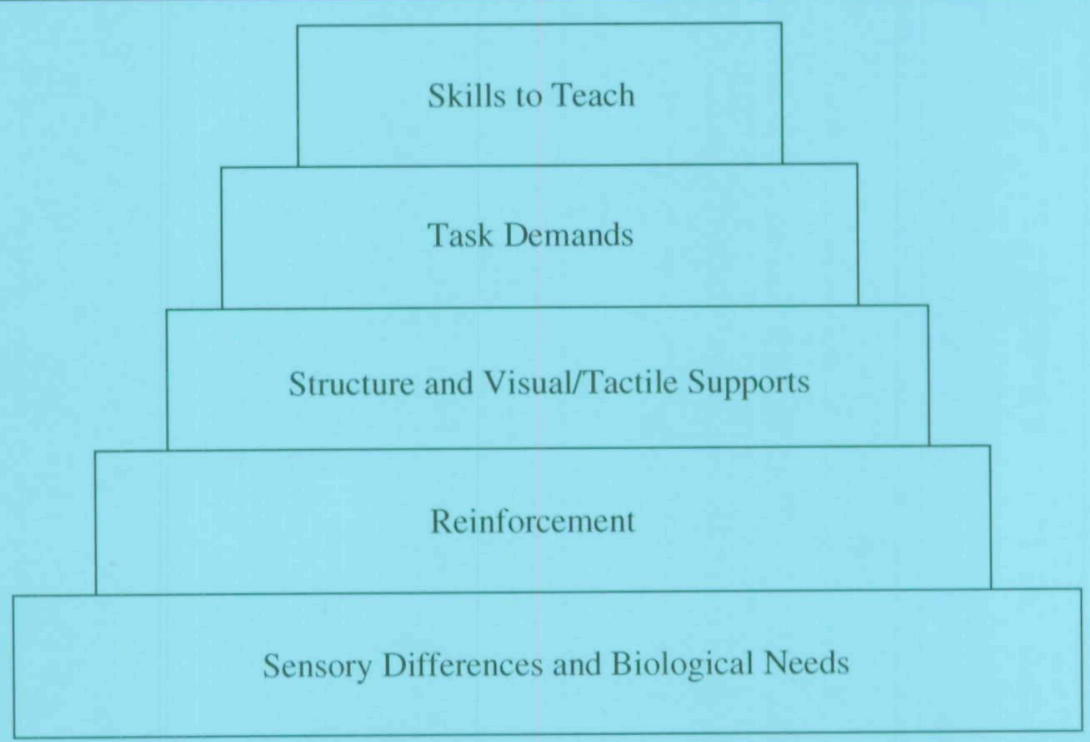

Source: From The Ziggurat Model: A Framework for Designing Comprehensive Interventions for Individuals with High-Functioning Autism and Asperger Syndrome, by R. Aspy \& B. G. Grossman, 2007. Shawnee Mission, KS: AAPC. Copyright 2007 by the AAPC. Reprinted with permission. 
peers on the playground, as he was a loner in this environment. In this case, the behavior, "loner" on the playground, was operationally defined as wandering the perimeter, flapping hands, shaking sticks in front of his eyes, and talking to himself. Using a traditional model, the antecedent was being on the playground at recess and all related environmental factors-noises, reduced structure, and so on. The most obvious consequence of this behavior was isolation from peers and the ability to engage in a chosen behaviorstereotypic stick shaking.

A program designed with this information in mind would typically provide (a) a shortened recess to reduce environmental overstimulation, (b) a peer buddy to interact with Rick during the shortened recess time, and (c) reinforcement for interacting with the peer. Although containing elements identified as evidence based, such a program will probably not bring about meaningful change and be generalizable.

However, if the behavior is approached from the perspective of the autism characteristics-the characteristics that underlie the observable behavior - the picture might be different, as depicted in Figure 3 using the Schopler (1994) iceberg. As illustrated, the characteristics that impact Rick's playground behavior include (a) mindblindness, (b) difficulty making friends, (c) difficulty joining an activity, (c) strong need for routine or sameness, (d) repetitive motor movement, (e) difficulty starting and joining a conversation, and (f) being easily stressed. It is these targets that must be addressed for Rick to be successful in interacting with others on the playground.

In summary, the process of intervention design should begin with an assessment of the presenting characteristics of ASD (see Figure 1). A thorough assessment of underlying characteristics helps parents and professionals to plan a program that takes into account the individual's strengths and needs. Further, assessment of underlying characteristics provides insight into which skills should be taught and how instruction should be designed to facilitate learning and bring about meaningful and long-lasting change. The Underlying Characteristics Checklist (UCC) offers a comprehensive perspective as a basis for program planning.

\section{The Underlying Characteristics Checklist ${ }^{1}$}

The UCC is an informal assessment designed to identify ASD characteristics for the purpose of intervention. There are three versions of the UCC, one intended for use with individuals who are high functioning (UCC-HF), including

'UCC items, the ISSI, the Global Intervention Plan, Ziggurat Worksheet, and CAPS form are presented in the case studies.

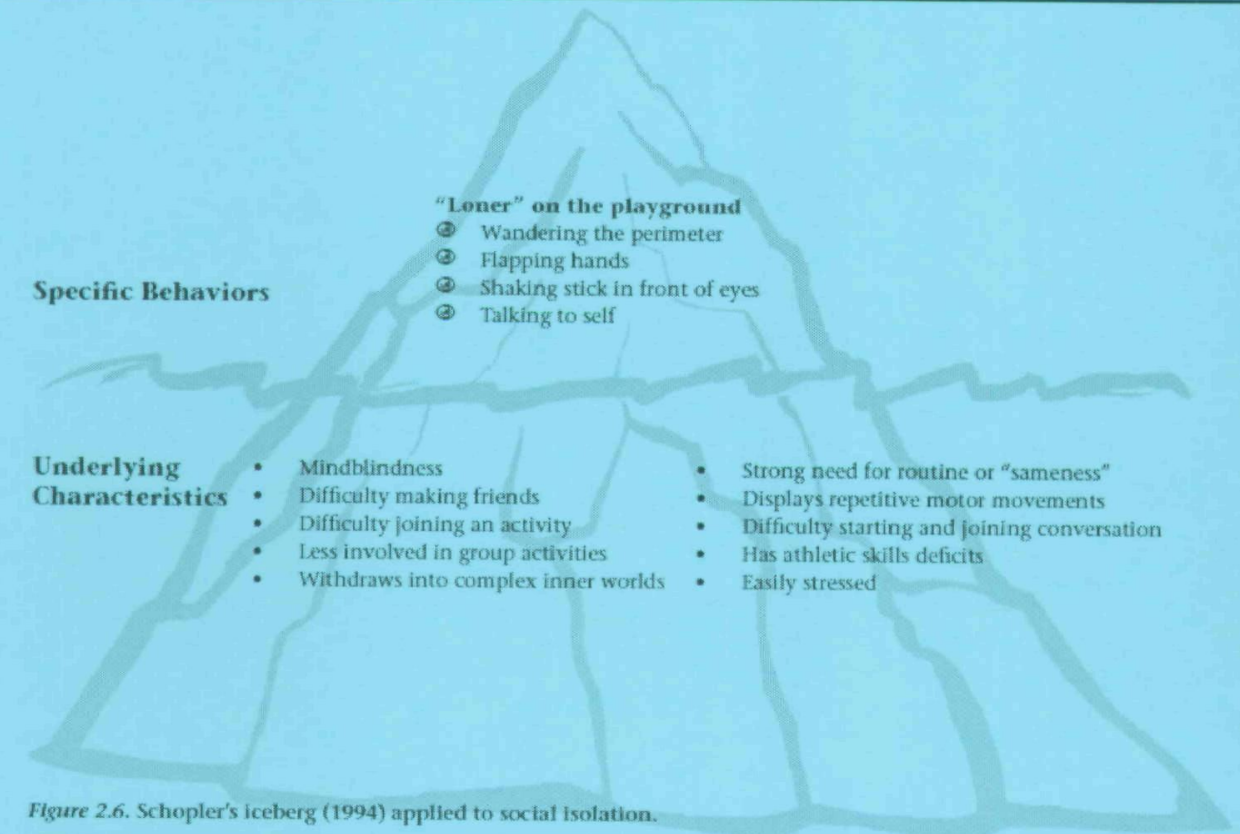

Source: From The Ziggurat Model: A Framework for Designing Comprehensive Interventions for Individuals with High-Functioning Autism and Asperger Syndrome, by R. Aspy \& B. G. Grossman, 2007. Shawnee Mission, KS: AAPC. Copyright 2007 by the AAPC. Reprinted with permission. 
those with Asperger Syndrome (AS); one for use with those with a more classic presentation (UCC-CL) in cognition and speech-language skills; and one for young children at the early invention stage, the UCC-EI.

Designed to be completed by parents, teachers, or other service providers, individually or as a team, each of the UCCs is composed of eight areas. The first three represent the traditional autism spectrum triad: social, restricted patterns of behavior interests and activities, and communication (see Wing, 1981). Characteristics often associated with ASD are addressed in the next four areas: sensory differences, cognitive differences, motor differences, and emotional vulnerability. The eighth underlying area is known medical and other biological factors (see Zecavati \& Spence, 2009). Based on the results of completing the UCC, a comprehensive intervention plan is developed that targets ASD characteristics by incorporating each of the five levels of the Ziggurat.

\section{The Individual Strengths and Skills Inventory}

The Individual Strengths and Skills Inventory (ISSI) (see Figure 4), designed to accompany the UCC, ensures that an individual's underlying strengths and skills are incorporated in the intervention design process. For example, one student may have a strength in imitation whereas another has an intense interest in and knowledge of animals. These assets can easily become keys to addressing underlying skill deficits. The ISSI parallels the first seven areas of the UCC - social, restricted patterns of behavior interests and activities, communication, sensory differences, cognitive differences, motor differences, and emotional vulnerability.

\section{Global Intervention Plan}

The global intervention plan helps users complete a person-centered plan by identifying short- and long-term goals and targeting the UCC areas and items that would have the greatest impact on the individual's ability to be independent and experience a sense of well-being across multiple environments. Using this tool, ASD-related areas are selected that will be meaningful in both the short and the long term. Thus, the student's educational plan will be tied directly to leading a self-determined life as a adult, replete with opportunities, happiness, and other aspects related to a high quality of life (Wigham et al., 2008).

\section{The Intervention Ziggurat}

The centerpiece and the framework of the Ziggurat Model is the Intervention Ziggurat (IZ). Designed to help parents and educators avoid overlooking critical areas that impact the effectiveness of any intervention plan as they build a comprehensive program, the IZ is composed of five critical levels structured into a hierarchy: sensory differences and biological needs, reinforcement, structure and visual/tactile supports, task demands, and skills to teach (see Figure 2). The first level, sensory differences and biological needs, addresses basic internal factors that impact functioning. The second level addresses motivational needs prerequisite to skill development. The third level draws on individuals' strength of visual processing and addresses their fundamental need for order and routine. The final two levels of the IZ emphasize the importance of expectations and skill development relative to the characteristics of individuals with ASD.

Each of the levels is essential and contributes to the effectiveness of the others. Thus, if needs on all levels are not addressed, the intervention will not be as effective and skills will not develop. The following is a brief discussion of the five levels of the IZ.

\section{Sensory Differences and Biological Needs}

The first level of the IZ represents what may be considered the foundation of behavior, biology. Consideration of biological factors is important because of the strong genetic and neurological underpinnings of ASD. Sensory differences and biological needs often present some of the greatest challenges for individuals on the spectrum. The existence of one of these areas, sensory, is being formalized by its proposed inclusion in the fifth edition of the American Psychiatric Association's (APA) Diagnostic and Statistical Manual of Mental Disorders (2010). Research supports the effective use of sensory interventions for individuals with ASD: More than 50 studies have been conducted on sensory interventions (see Baranek, 2002; Case-Smith \& Arbesman, 2008). Much of the research on biological interventions has centered on the use of medications, both conventional (Angley, Young, Ellis, Chan, \& McKinnon, 2007) and complementary and alternative (Angley, Semple, Hewton, Paterson, \& McKinnon, 2007).

\section{Reinforcement}

All intervention plans ultimately target the development or increase of a behavior or skill. This goal can only be accomplished by incorporating reinforcement into a comprehensive plan, given that the purpose of intervention is to increase the likelihood that a behavior will occur again. Without reinforcement, there is no intervention. Therefore, reinforcement is included as the second level of the IZ (see Figure 2). It is often challenging to identify appropriate reinforcers for individuals on the spectrum, but consideration of a student's preoccupations or special interests has been found to be effective (Winter-Messiers, 2007). Indeed, research has found that activities or objects related to obsessions are often more effective reinforcers than food (see Charlop-Christy, Kurtz, \& Casey, 1990) for individuals on the autism spectrum. The principles of effective reinforcement are well 
established in the research literature. In fact, the most effective intervention programs deliver reinforcement for positive behaviors and limit access to reinforcement of problem behaviors (see Horner, Carr, Strain, Todd, \& Reed, 2002).

\section{Structure and Visual/Tactile Supports}

Individuals with ASD function best when predictability is established across the school day, including schedules, routines, environments, behavioral and academic expectations, and interpersonal interactions. In order to be successful in home, school, and community, those on the spectrum require preparation. Because verbal communication deficits are evident with ASD, supports that are visual are critical. For students with ASD and a vision impairment, tactile supports should be considered. Visual supports, such as pictures, written schedules, and task strips, have been shown to be effective for decreasing behavior problems, increasing on-task behavior, and enhancing independence (see Wheeler, Baggett, Fox, \& Blevins, 2006). There is substantial research support for other visual strategies, such as Social Stories $^{\mathrm{TM}}$ and video modeling (see Wang \& Spillane, 2009).

\section{Task Demands}

The term task demand can be thought of as obstacle removal (E. Blackwell, personal communication, July 12, 2007). In designing quality interventions, obstacles that could prevent an individual from succeeding either independently or with assistance should be taken away. For example, a team may recognize that a child lacks the skills to negotiate peer conflict and, therefore, provide him with a trained peer "buddy" during group activities until he is able to master strategies for compromise. The obstacle: lacking the skills to negotiate peer conflict; how it is removed: providing a trained peer buddy who can help the child in situations that require compromise. Task demands with the IZ include academic demands but go beyond, to include social, communication, organizational, sensory, and other areas of functioning. Numerous interventions reduce demands. For example, peer-mediated interventions, including peer networks, circle of friends, and peer buddies have been found to be beneficial in promoting social skills (Chan et al., 2009).

\section{Skills to Teach}

The first four levels of the Ziggurat set the stage for skill acquisition. It is possible to resolve many behavior concerns using strategies on the first four levels without ever teaching skills. Indeed, many improvements may be seen as a direct result of attending to an individual's biological needs, providing meaningful reinforcers, addressing the need for structure and predictability, and carefully matching demands to ability.
Comfortable with behavior gain, intervention teams may overlook the crucial last level-skills to teach. However, such a "partial" approach to intervention will have negative long-term outcomes because it does not allow for independence nor does it promote generalization or growth. It is for this reason that the authors view skills to teach as the ultimate goal of any intervention plan. Several approaches to teaching skills to individuals with ASD have been supported in the literature, including instruction during social skills groups (see Wang \& Spillane, 2009) and pivotal response training (PRT; see Harper, Symon, \& Frea, 2008).

Using the aforementioned information, the team uses the Ziggurat Worksheet to guide them through the development of a comprehensive intervention plan. With a new understanding of the student's needs based on (a) completion of the UCC, (b) the information on strengths and current skill level gained through completion of the ISSI, and (c) the development of long- and short-term goals and prioritized UCC areas and items using the global intervention plan, the team is prepared to design an intervention plan that is targeted to the individual student.

\section{Ziggurat Worksheet}

All interventions incorporated into the plan must address underlying needs from the UCC. This provides a safeguard from developing a plan that addresses only surface concerns or from recycling interventions that have been used with other students with ASD without careful consideration of the specific student. Further, the Ziggurat Worksheet promotes collaboration by helping parents and professionals to understand their respective parts in the larger intervention picture. After completion of the Ziggurat Worksheet, the team is ready to discuss how these interventions will be embedded throughout the school day. While the Ziggurat Worksheet allows a team to know that the intervention plan is thorough and targeted, the Comprehensive Autism Planning System provides a structure for implementation, as detailed further below.

\section{WHAT IS THE COMPREHENSIVE AUTISM PLANNING SYSTEM (CAPS)?}

CAPS provides an overview of a student's daily schedule by time and activity and specifies supports needed during each period. Thus, the CAPS enables professionals and parents to answer the fundamental question: What supports does the student need for each activity?

Once a multidisciplinary team, including the student's parents, has (a) identified the student's needs through completion of the UCC (CL, HF, or EI) and ISSI, (b) established goals for the student and prioritized UCC items that lead to these goals, and (c) developed interventions across the six 
areas of the Ziggurat that match the student's UCC- and ISSI-identified strengths and concerns, the team is ready to complete the CAPS. That is, based on information developed using the Ziggurat Model, the CAPS provides a framework for listing a student's tasks and activities and the times they occur, along with a delineation of the supports needed for success. In addition, the CAPS includes a place for recording the results of ongoing data collection and consideration of how skills are to be generalized to other settings.

\section{Components of CAPS}

The CAPS contains the following components:

1. Time. This section indicates the clock time of each activity that the student engages in throughout the day.

2. Activity. This includes all tasks and activities throughout the day in which the student requires support. Academic periods (e.g., reading), nonacademic times (e.g., recess, lunch), as well as transitions between classes are all considered activities.

3. Targeted skills to teach. This may include Individualized Education Program (IEP) goals, state standards, and/or skills that lead to school success for a given student.

4. Structure/modifications. Structures/modifications can consist of a wide variety of supports, including placement in the classroom, visual supports, peer networks and instructional strategies (e.g., priming, self-monitoring).

5. Reinforcement. Student access to specific types of reinforcement as well as reinforcement schedules are listed here.

6. Sensory strategies. Sensory supports and strategies identified by an occupational therapist or others are listed in this CAPS area.

7. Communication/social skills. Specific communication goals or activities as well as supports are delineated in this section. Goals or activities may include (a) requesting help, (b) taking turns in conversation, or (c) protesting appropriately. Supports may encompass language boards or augmentative communication systems.

8. Data collection. This space is for recording the type of data as well as the behavior to be documented during a specific activity. Typically, this section relates directly to IEP goals and objectives.

9. Generalization plan. Because individuals with ASD often have problems generalizing information across settings, this section of the CAPS was developed to ensure that generalization of skills is built into the child's program.
The CAPS, as well as the Ziggurat Model, are applicable from early intervention to adulthood across home, school, employment, university or postsecondary training, and community. However, some slight modifications in the CAPS are needed as the individual enters high school and beyond. When students transition to middle and high school, the daily structure of school changes. For example, students may have as many as nine teachers in nine different classrooms. Despite their movement from classroom to classroom, the activities in which students participate in each academic class are similar. That is, in each class they are likely to be required to participate in (a) independent work, (b) group work, (c) tests, (d) lectures, and (e) homework. From this standpoint, the activities in English class and geometry are the same.

The fundamental differences between the structure of elementary school and middle/high school require that the CAPS must be modified accordingly. The Modified Comprehensive Autism Planning System (M-CAPS) is an effective means of communicating to educators who teach academic subjects the types of supports that students need during each activity (Sue Klingshirn, personal communication, April 7, 2006). The multidisciplinary team that plans the program for a high school student with ASD who spends extensive time in general education classrooms develops the student's program using the M-CAPS. As a result, each of the student's academic teachers shares the same document. The M-CAPS used in biology is the same as the M-CAPS used in sociology. Likewise, the supports for a given student are the same.

\section{CASE STUDIES}

The following describes how the Ziggurat Model and CAPS were used with two individuals with ASD: Emily, a 3-year-old with classic autism, and Reggie, a 15-year-old with AS.

\section{Case Study for Emily: From Ziggurat to CAPS}

Emily, a 3-year-old child attending an early childhood program in a public school, has been identified with ASD and speech impairment. Emily can label objects and make one-word requests when prompted. She does not initiate communication or social interaction with adults or peers. Eye contact is fleeting, and she seems to display limited interest in others. Emily withdraws from group activities and spends extended periods of time engaged in repetitive behaviors, such as jumping and wiggling her fingers in her peripheral vision. Emily requires prompting in order to engage in play and extended social interactions.

Parents and teachers believe that if Emily could stay on task longer, she would make more progress at home and in school. They have expressed concern about apparent sensory 
differences, as Emily frequently smells and mouths objects and toys, is bothered by loud or unexpected noises, startles at unexpected movement, and has difficulty participating in groups in a loud environment. She becomes distressed when her teeth are brushed. Emily also seeks movement: She often shakes objects in her peripheral vision, rocks, and jumps. Emily appears to be visually distracted and captivated by straight lines such as miniblinds and corners of shelves, books, frames, and so on.

Interventions tried in the past include interactive metronome, therapeutic listening, and chelation. Parents report that these interventions have resulted in no change in Emily's behaviors and skill acquisition. The school provides the following sensory interventions: a weighted vest, a weighted lap pad, picture schedules, and use of a colorcoded square for positioning during circle time. Emily receives speech therapy at school and participates in outpatient occupational therapy sessions three times per week.

Emily's multidisciplinary team, including her parents, met to develop her program. They completed a UCC, an ISSI (see Figure 4), UCC-EI, and Global Planning Guide (see Figure 5 for the guide that also includes UCC-EI items). Using information from these activities, Emily's team completed the Ziggurat Worksheet (see partial copy in Figure 6). Finally, they created a CAPS for her school program (see partial copy in Figure 7).

When designing an effective intervention plan, it is important to consider individual strengths.

Please describe strengths in the following areas:

Social

- Kind child

- Engages best during predictable, repetitive activities

- Engages in parallel play in quite settings

- Plays with sister at home

- Responds well to parent praise

Behavior, Interests, and Activities

- Does very well with structure

- Prefers activities that are routine/predictable

Communication

- Able to repeat words

- Able to label objects and make simple requests with prompting

Sensory

- Enjoys sand play

- Eats a range of textures

- Good hearing

Cognitive

- Good memory

- Maintains skills

Motor

- Enjoys jumping, running, and climbing

- Strong

- Plays best during activities involving movement

Emotional

- Happy child

Biological

- Strong

- Healthy

- Sleeps well

Source: From The Ziggurat Model: A Framework for Designing Comprehensive Interventions for Individuals with High-Functioning Autism and Asperger Syndrome, by R. Aspy \& B. G. Grossman, 2007. Shawnee Mission, KS: AAPC. Copyright 2007 by the AAPC. Reprinted with permission. 
Directions: Following completion of the UCC and ISSI, the next step is to identify UCC areas and items that will result in a meaningful Global Intervention Plan. Consideration of priorities and strengths for an individual facilitates selection of UCC areas and items. The following questions are provided as a guide.

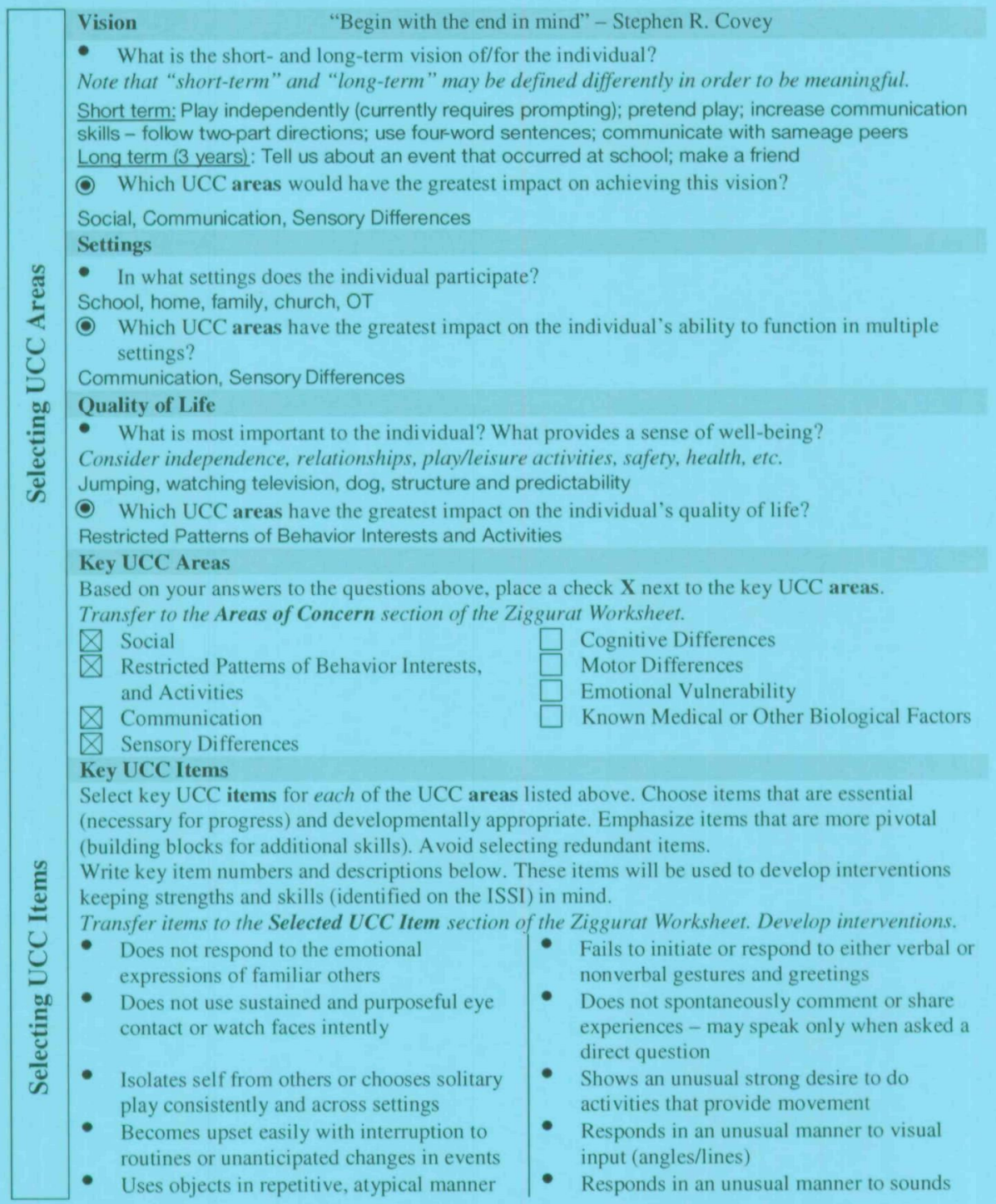

Source: From The Ziggurat Model: A Framework for Designing Comprehensive Interventions for Individuals with High-Functioning Autism and Asperger Syndrome, by R. Aspy \& B. G. Grossman, 2007. Shawnee Mission, KS: AAPC. Copyright 2007 by the AAPC. Reprinted with permission.

\section{FIGURE 5. Global Intervention Plan: Guide to Establishing Priorities: Emily}

\section{Case Study for Reggie: From Ziggurat to CAPS}

Reggie is a 15-year-old who was diagnosed with AS at age 9 . He lives with his mother and two younger brothers; one is diagnosed with attention deficit-hyperactivity disorder, and the other has learning disabilities.

Throughout elementary school, Reggie received special education services, including speech and language therapy focused on pragmatic language and social skills and occupational therapy. The majority of his day was spent in the general education classroom with supplemental instruction in language arts in a resource room. After transitioning to middle school, Reggie no longer received direct therapy services. He is currently in the third quarter of his freshman year of high school. He attends all general education classes, 


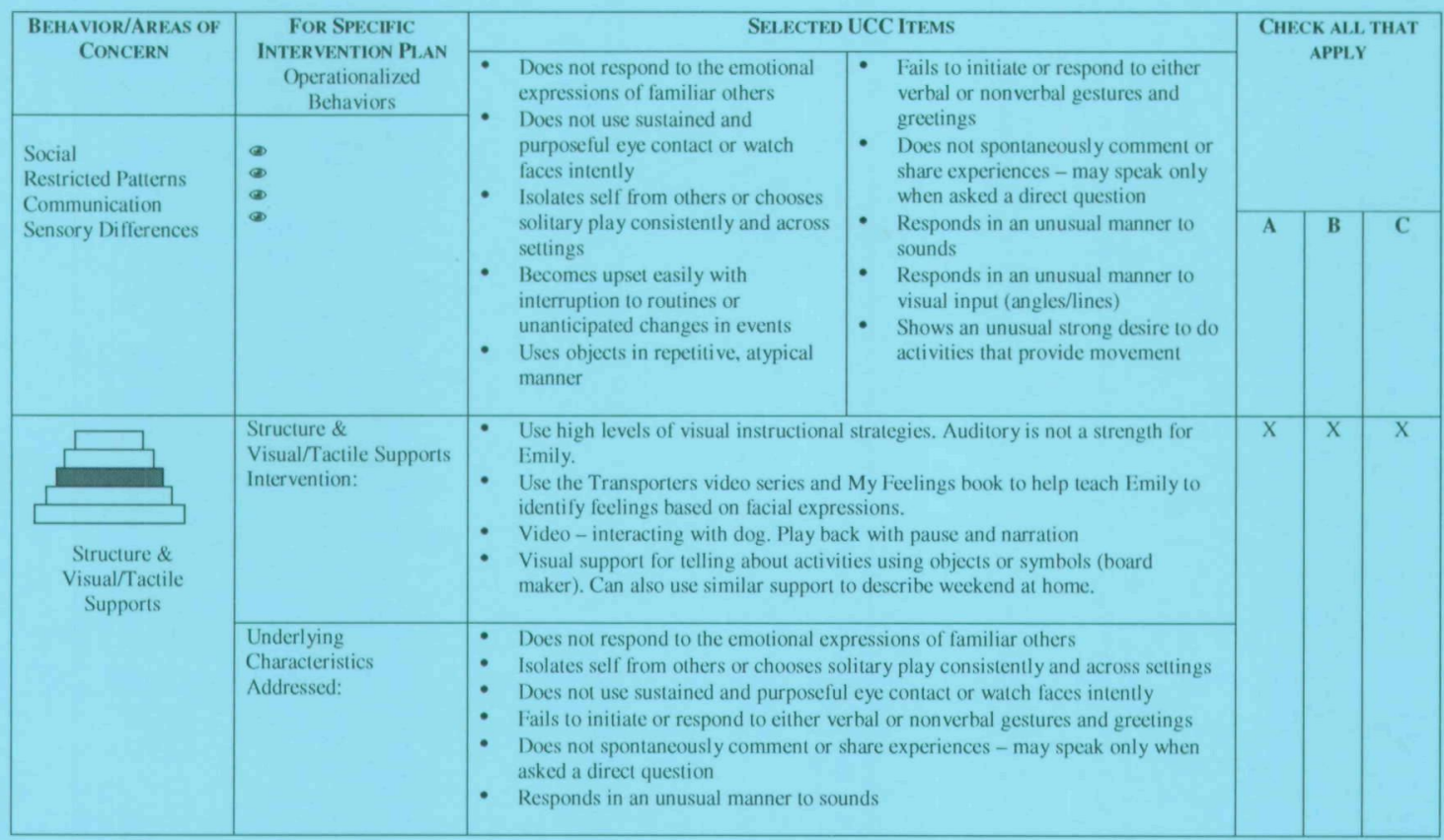

Source: From The Ziggurat Model: A Framework for Designing Comprehensive Interventions for Individuals with High-Functioning Autism and Asperger Syndrome, by R. Aspy \& B. G. Grossman, 2007. Shawnee Mission, KS: AAPC. Copyright 2007 by the AAPC. Reprinted with permission.

FIGURE 6. Ziggurat Worksheet: Emily (Partial)

\begin{tabular}{|c|c|c|c|c|c|c|c|c|}
\hline E & $\frac{2}{3}$ & 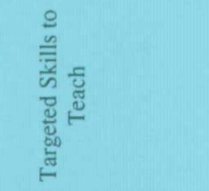 & 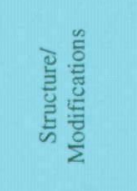 & 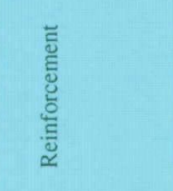 & 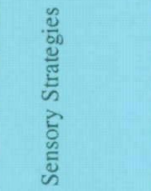 & 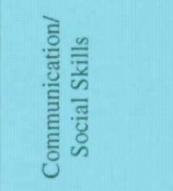 & 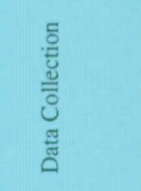 & 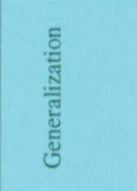 \\
\hline $9: 00$ & Arrival & $\begin{array}{l}\text { Complete arrival } \\
\text { steps independently } \\
\text { Greetings } \\
\text { Emotion check }\end{array}$ & $\begin{array}{l}\text { Task strip of } \\
\text { arrival steps } \\
\text { Emotion } \\
\text { check-in } \\
\text { poster }\end{array}$ & $\begin{array}{l}\text { Reinforcement } \\
\text { menu (after } \\
\text { arrival steps) }\end{array}$ & Fidget & $\begin{array}{l}\text { Language board } \\
\text { Prompt to greet } \\
\text { (fade) }\end{array}$ & $\begin{array}{l}\text { D: \# steps, } \\
\text { greetings I, } \\
P \\
\text { Emotion } \\
(\mathrm{y} / \mathrm{n})\end{array}$ & $\begin{array}{l}\text { Task strip at } \\
\text { home for } \\
\text { bedtime } \\
\text { routine }\end{array}$ \\
\hline $9: 10$ & Priming & $\begin{array}{l}\text { Use language board } \\
\text { to initiate, respond, } \\
\text { comment }\end{array}$ & $\begin{array}{l}\text { Visual } \\
\text { schedule }\end{array}$ & $\begin{array}{l}\text { Verbal } \\
\text { reinforcement }\end{array}$ & $\begin{array}{l}\text { Fidget or hold } \\
\text { toy dog } \\
\text { Carpet square }\end{array}$ & $\begin{array}{l}\text { Language board } \\
\text { Labeled area } \\
\text { with icons to } \\
\text { match schedule }\end{array}$ & $\begin{array}{l}\text { M: \# } \\
\text { initiations, } \\
\text { responses, } \\
\text { comments; } 5 \\
\text { min. }\end{array}$ & $\begin{array}{l}\text { Language } \\
\text { board at } \\
\text { home } \\
\text { Fidget at } \\
\text { home }\end{array}$ \\
\hline $9: 30$ & $\begin{array}{l}\text { Literacy/ } \\
\text { Language } \\
\text { Group }\end{array}$ & $\begin{array}{l}\text { Use language board } \\
\text { to initiate, respond, } \\
\text { comment } \\
\text { State standards } \\
\text { Recognize emotion } \\
\text { Independent } \\
\text { transition to activity }\end{array}$ & $\begin{array}{l}\text { Task strip of } \\
\text { activities } \\
\text { Visual } \\
\text { schedule }\end{array}$ & $\begin{array}{l}\text { Interacting with } \\
\text { peers } \\
\text { Verbal }\end{array}$ & $\begin{array}{l}\text { Fidget } \\
\text { Carpet square }\end{array}$ & $\begin{array}{l}\text { Language board } \\
\text { Labeled area } \\
\text { with icons to } \\
\text { match schedule } \\
\text { Transporters } \\
\text { My Feelings } \\
\text { book }\end{array}$ & $\begin{array}{l}\mathrm{T} \#(5 \mathrm{~min}) \\
\text { initiations, } \\
\text { responses, } \\
\text { comments; } \\
\text { Grade book } \\
\mathrm{T} \# \text { steps, } \mathrm{I} \text {, } \\
\mathrm{P}\end{array}$ & $\begin{array}{l}\text { Read books } \\
\text { at home }\end{array}$ \\
\hline
\end{tabular}

Note $\mathrm{D}=$ daily, $\mathrm{I}=$ independent, $\mathrm{P}=$ prompt, $\mathrm{M}=$ Monday, $\mathrm{T}=$ Tuesday.

Source: From The Comprehensive Autism Planning System (CAPS) for Individuals with Asperger Syndrome, Autism and Related Disabilities: Integrating Best Practices throughout the Student's Day, by S. A. Henry \& B. S. Myles, 2007. Shawnee Mission, KS: AAPC. Copyright 2007 by the AAPC. Reprinted with permission. 
including biology, history, English literature, algebra, composition, and PE. His schedule also includes a daily support period where he is given assistance with organizational and social skills.

Reggie has a special interest in sports statistics and memorabilia. In fact, he would rather look at sports magazines than interact with peers. He has memorized a plethora of statistics of almost every Major League baseball player and can easily recall scores of baseball games played since the founding of the National League in 1876. He often cites those statistics in conversation.

Reggie processes information presented visually and does well when expectations, directions, and schedules are presented in written instead of verbal form. He is extremely sensitive to sound. In addition, he has difficulty reading facial expressions and body language. Although Reggie has an IQ in the above-average range, he receives primarily $\mathrm{Cs}$ and Ds on his report card, because a significant portion of his grades is based on homework assignments that he forgets to record in his planner and, as a result, fails to complete and turn in. In addition, he does not bring home materials needed to complete assignments.

Reggie excels in math and in history; however, he struggles with literature and composition. Handwriting is laborious for him. In addition, his teachers report that he is anxious in classes - he has difficulty tolerating mistakes, gets upset when he receives a poor grade on a test, and frequently argues with his teachers over his grades. Reggie also experiences challenges in $\mathrm{PE}$, where he becomes increasingly anxious when the noise level is high. When participating in team sports, he removes himself from the game and sits on the sidelines. When his teacher approaches him to discuss the situation, Reggie insists that his peers are intentionally trying to hurt him. Recently, these situations have increased in both number and intensity. His teacher thinks that Reggie is a "sore loser."

Reggie's multidisciplinary team, including his parents, met to develop his program. They completed a UCC-HF and ISSI (see Figure 8). The team completed a Global Intervention Plan to prioritize areas of need (see Figure 9). Using information from these activities, Reggie's team completed the Ziggurat Worksheet (see partial copy in Figure 10). Finally, they created a CAPS for his general education classes (see partial copy in Figure 11) and a traditional CAPS for his PE class (see Figure 12).
One intervention that will facilitate communication among team members, including parents, is the Travel Card. Briefly, across the top, the Travel Card lists four to five target behaviors the student is working on with a listing of the classes the student attends along the left-hand side. At the end of each period, the teacher indicates whether the student performed the desired behaviors by marking a + (yes), 0 (no), or NA (not applicable) on the card. The student's last teacher of the day takes the travel card and places it in the case manager's mailbox. In this way, the case manager has a daily report on critical student behaviors. The Travel Card can be used in conjunction with a reinforcement system.

\section{SUMMARY}

Research in the area of ASD demonstrates an understanding of evidence-based practices in isolation. To make sustainable change in the quality of life for an individual with ASD, it is essential that we determine whether a particular intervention or, more likely, sets of interventions matches his or her strengths and needs. This requires a thorough understanding of the student's needs, especially those related to the underlying characteristics of ASD. The UCC at any level (HF, CL, or EI) provides a tool for teams to identify those strengths and needs as a basis for developing goals and strategies to help in selecting the most appropriate instructional strategies.

The Ziggurat Model provides tools, including the ISSI, the Global Intervention Plan, and the Ziggurat Worksheet, for matching goals and prioritizing interventions. Integrating these strategies systematically and comprehensively throughout the individual's day in a comprehensive plan provides for continual development of student skills. To maximize educational benefit, practices must be used competently and consistently (Fixsen et al., 2009). Lastly, measurement of those skills with a vision of the effect on the student now and in the future is a final critical step to achieve sustained change (NRC, 2001). Such implementation usually requires changes in the daily activities of staff, related service providers, administrators, and even parents. It takes cohesive team planning, clearly defined objectives, and professional development of all personnel to ensure that the chosen evidence-based strategies are implemented with fidelity and across all settings. The Ziggurat Model and CAPS provide a vehicle by which this can occur. 
In designing effective intervention plans, it is important to be aware of individual strengths.

Please describe strengths in the following areas:

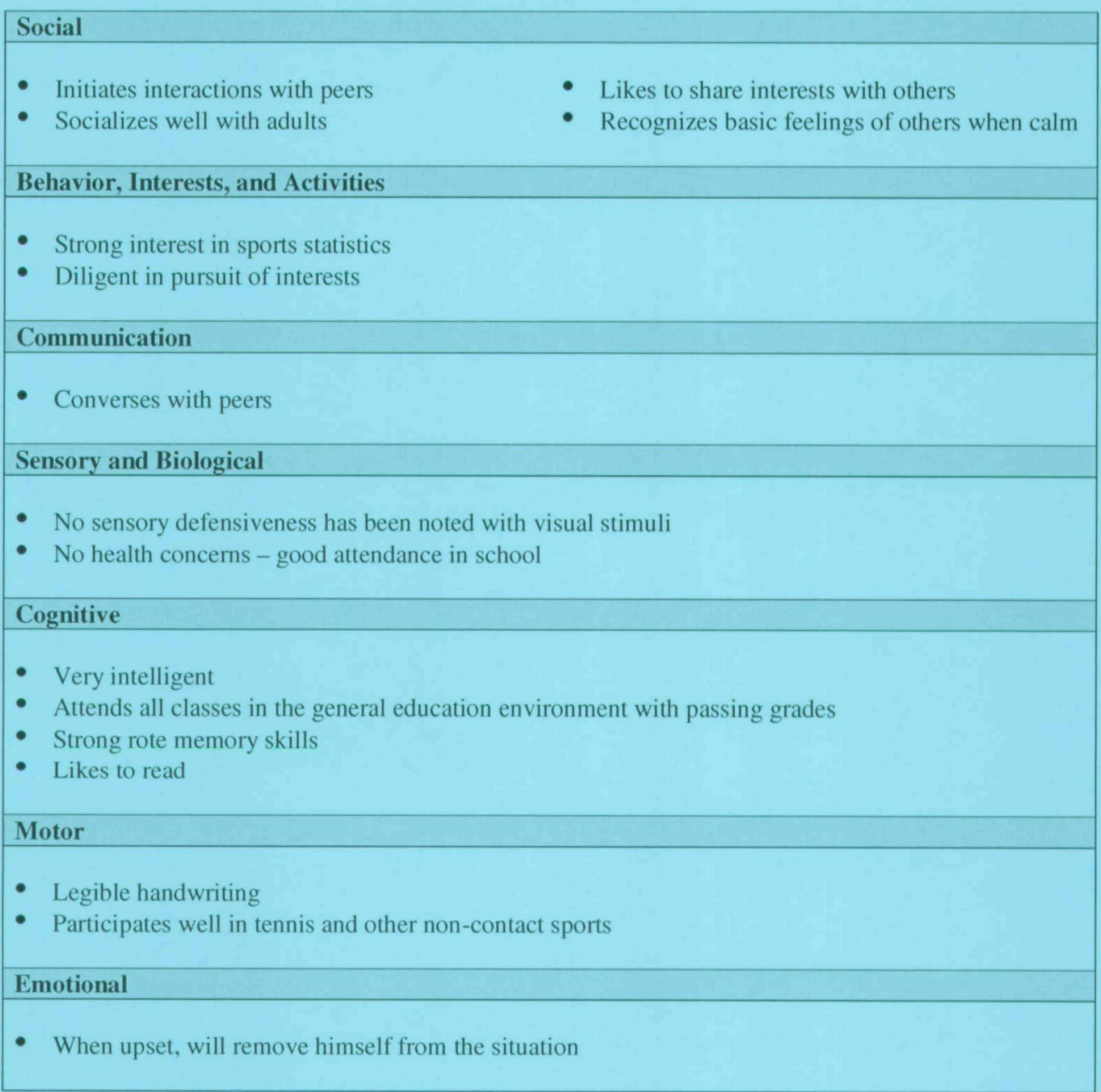

Source: From The Ziggurat Model: A Framework for Designing Comprehensive Interventions for Individuals with High-Functioning Autism and Asperger Syndrome, by R. Aspy \& B. G. Grossman, 2007. Shawnee Mission, KS: AAPC. Copyright 2007 by the AAPC. Reprinted with permission.

FIGURE 8.

Individual Strengths and Skills Inventory: Reggie 
Directions: Following completion of the UCC and ISSI, the next step is to identify UCC areas and items that will result in a meaningful Global Intervention Plan. Consideration of priorities and strengths for an individual facilitates selection of UCC areas and items. The following questions are provided as a guide.

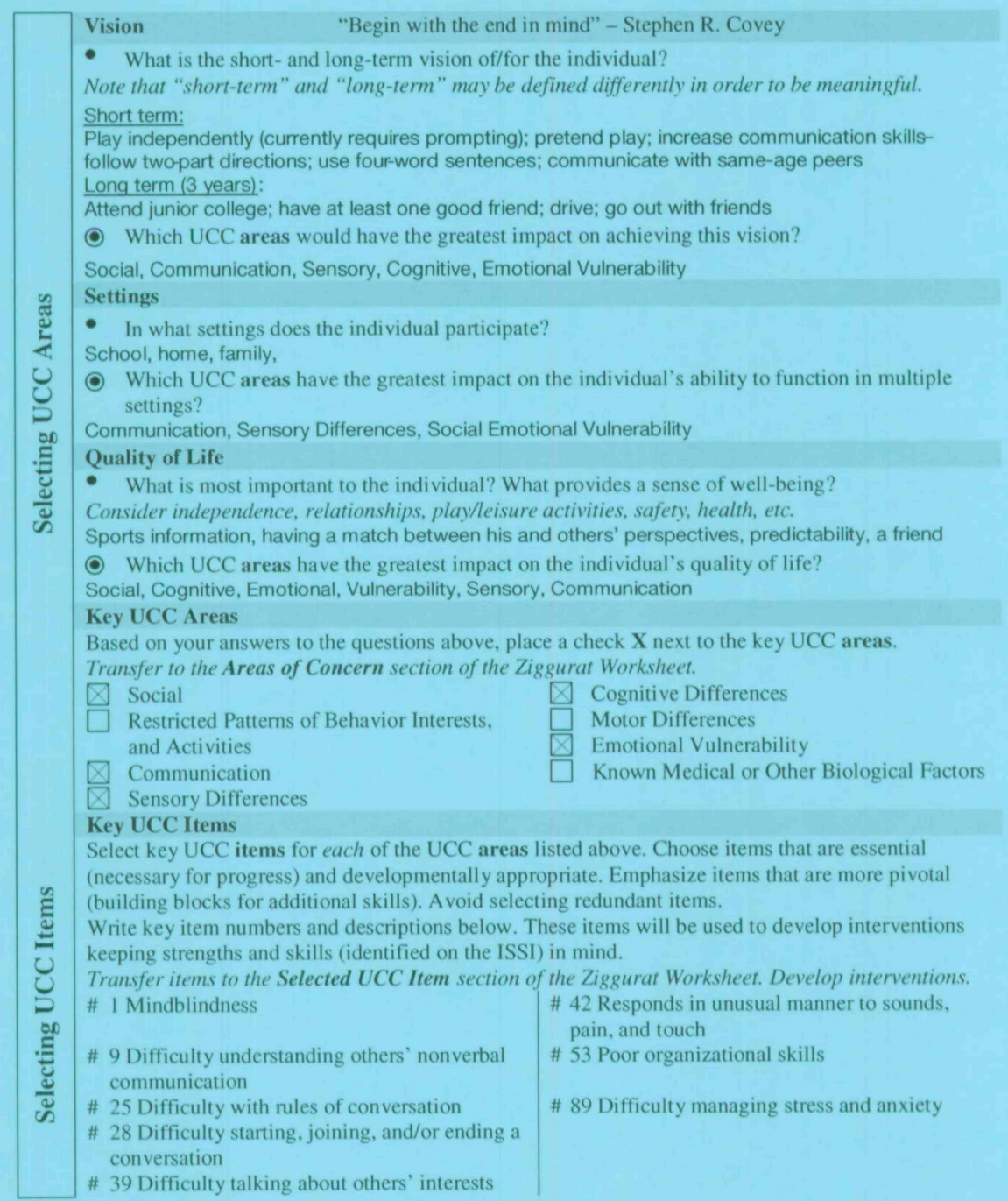

Source: From The Ziggurat Model: A Framework for Designing Comprehensive Interventions for Individuals with High-Functioning Autism and Asperger Syndrome, by R. Aspy \& B. G. Grossman, 2007. Shawnee Mission, KS: AAPC. Copyright 2007 by the AAPC. Reprinted with permission.

FIGURE 9.

Global Intervention Plan: Guide to establishing priorities: Reggie 


\begin{tabular}{|c|c|c|c|c|c|c|}
\hline AREAS OF CONCERN & $\begin{array}{l}\text { SPECIFIC INTER VENTION } \\
\text { PLAN }\end{array}$ & \multicolumn{2}{|c|}{ PRIORITIZED UCC ITEMS } & & & \\
\hline \multirow{2}{*}{$\begin{array}{l}\text { Social, Communication, } \\
\text { Sensory, Cognitive, } \\
\text { Emotional Vulnerability }\end{array}$} & \multirow{2}{*}{ Operationalized Behaviors } & \multirow{2}{*}{$\begin{array}{l}\text { \# [1] Mindblindness } \\
\text { \# [9] Difficulty understanding others' } \\
\text { nonverbal communication } \\
\text { \# [25] Difficulty with rules of conversation } \\
\text { \# [28] Has difficulty starting, joining, } \\
\text { and/or ending a conversation }\end{array}$} & \multirow{2}{*}{$\begin{array}{l}\text { \# [39] Difficulty talking about others' } \\
\text { interests } \\
\text { \# [42] Responds in unusual manner to } \\
\text { sounds, pain, and touch } \\
\text { \# [53] Has poor organizational skills } \\
\text { \# [89] Difficulty managing stress and } \\
\text { anxiety }\end{array}$} & \multicolumn{3}{|c|}{ CHECK ALL THAT APPLY } \\
\hline & & & & $\mathbf{A}$ & B & C \\
\hline & $\begin{array}{l}\text { Sensory/Biological } \\
\text { Intervention: }\end{array}$ & \multicolumn{2}{|c|}{$\begin{array}{l}\text { Teach Reggie relaxation techniques including calming sensory strategies } \\
\text { - Use portable coping cards to help Reggie to calm in all school settings (see below) } \\
\text { Provide short breaks that may include errand running }\end{array}$} & \multirow[t]{2}{*}{$\sqrt{ }$} & \multirow[t]{2}{*}{$\sqrt{ }$} & \\
\hline Sensory/Biological Needs & $\begin{array}{l}\text { Underlying Characteristics } \\
\text { Addressed: }\end{array}$ & \multicolumn{2}{|c|}{$\begin{array}{l}\text { - Difficulty managing stress and anxiety } \\
\text { - Responds in unusual manner to sounds, pain, and touch }\end{array}$} & & & \\
\hline Reinforcement & Reinforcement Intervention: & \multicolumn{2}{|c|}{$\begin{array}{l}\text { - Reinforcer menu (created with Reggie) and provide on a chart (be sure to } \\
\text { incorporate his sports interests) } \\
\text { - Reinforce skills across settings in order for Reggie to generalize them. As such, } \\
\text { parents should be taught how to use the system. } \\
\text { - Reinforce Reggie for using calming skills, completing homework checklist, } \\
\text { completing homework, using appropriate conversational manners }\end{array}$} & \multirow[t]{2}{*}{$\sqrt{ }$} & \multirow[t]{2}{*}{$\sqrt{ }$} & \multirow[t]{2}{*}{$\sqrt{ }$} \\
\hline & $\begin{array}{l}\text { Underlying Characteristics } \\
\text { Addressed: }\end{array}$ & \multicolumn{2}{|c|}{$\begin{array}{l}\text { - Difficulty with rules of conversation } \\
\text { - Pindblindness } \\
\text { - Difficulty managing stress and anxiety }\end{array}$} & & & \\
\hline Structure \& Visual Supports & $\begin{array}{l}\text { Structure/Visual Support } \\
\text { Intervention: }\end{array}$ & \multicolumn{2}{|c|}{$\begin{array}{l}\text { - Reinforcer menu/chart available for Reggie to reference } \\
\text { Use of stress thermometer to help teach Reggie about anxiety and recognize the } \\
\text { signs that indicate when he needs to use his coping strategies. Adults can prompt } \\
\text { Reggie to monitor/recognize his stress level by saying, "What's your stress } \\
\text { temperature?" } \\
\text { - Use coping cards - these are small, portable cards that have Reggie's coping skills } \\
\text { listed on them. Prompt Reggie to use cards. Provide reinforcement for both } \\
\text { prompted and unprompted use of cards. Fade prompts over time. } \\
\text { - Provide a problem-solving flow chart as a visual support for Reggie. } \\
\text { - Create task card that breaks assignment steps into smaller segments. } \\
\text { Use Social Stories }{ }^{T M} \text { to teach Reggie about interrupting in class and about how } \\
\text { different people have different interests. } \\
\text { - Use video to help Reggie learn conversational manners and related skills. } \\
\text { - } \text { - Pre help card so that Reggie can ask for help nonverbally. } \\
\text { so he can refer to it in class. Reinforce Reggie for using appropriate conversational } \\
\text { manners. } \\
\text { - Use cartooning to help Reggie understand what the listener (whole class) is thinking } \\
\text { and feeling when he interrupts or dominates a conversation. } \\
\text { Use homework checklist to assist Reggie in keeping up with assignments and } \\
\text { materials required to complete his homework. A teacher should first work directly } \\
\text { with Reggie to teach and supervise the use of the checklist. Reinforcement should be } \\
\text { provided for accurate completion of the checklist. Over time, fade adult assistance } \\
\text { but maintain reinforcement. } \\
\text { Use calendar to break down large class assignments into smaller parts with separate } \\
\text { due dates. } \\
\text { - Copies of notes for lectures; Reggie will highlight items covered during lecture. } \\
\text { Use a Travel Card to keep track of (a) assignment completion, (b) homework turned } \\
\text { in, (c) emotional regulation, (d) bringing supplies in class. Fade from teacher } \\
\text { responsibility to student responsibility. Tie events (a-d) to reinforcement system. }\end{array}$} & $\sqrt{ }$ & $\sqrt{ }$ & $\sqrt{ }$ \\
\hline
\end{tabular}

Source: From The Ziggurat Model: A Framework for Designing Comprehensive Interventions for Individuals with High-Functioning Autism and Asperger Syndrome, by R. Aspy \& B. G. Grossman, 2007. Shawnee Mission, KS: AAPC. Copyright 2007 by the AAPC. Reprinted with permission.

FIGURE 10.

Ziggurat Worksheet: Reggie (Partial) 


\begin{tabular}{|c|c|c|c|c|c|c|c|}
\hline 总 & 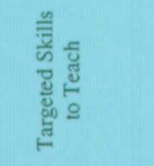 & ฏ. है & 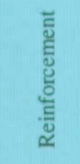 & 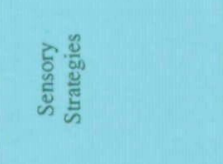 & 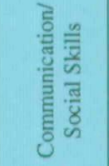 & 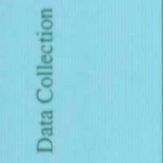 & 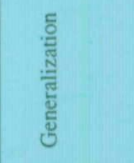 \\
\hline $\begin{array}{l}\text { Independent } \\
\text { Work }\end{array}$ & $\begin{array}{l}\text { Task } \\
\text { completion }\end{array}$ & $\begin{array}{l}\text { Stress thermometer } \\
\text { Task cards } \\
\text { Homework checklist } \\
\text { Calendar of long-term } \\
\text { assignments } \\
\text { Travel Card }\end{array}$ & $\begin{array}{l}\text { Menu } \\
\text { Verbal }\end{array}$ & Coping cards & Help card & $\begin{array}{l}\text { Grade book } \\
\text { (accuracyl } \\
\text { turned in) }\end{array}$ & $\begin{array}{l}\text { Coping cards } \\
\text { throughout } \\
\text { day }\end{array}$ \\
\hline Group Work & $\begin{array}{l}\text { Participation, } \\
\text { appropriate } \\
\text { with peers }\end{array}$ & $\begin{array}{l}\text { Homework checklist } \\
\text { Travel Card }\end{array}$ & Verbal & $\begin{array}{l}\text { Coping cards } \\
\text { Break after group } \\
\text { work }\end{array}$ & $\begin{array}{l}\text { Conversa } \\
\text { tion cue } \\
\text { card }\end{array}$ & $\begin{array}{l}\text { All peers will } \\
\text { rate each } \\
\text { other's } \\
\text { participation }\end{array}$ & $\begin{array}{l}\text { Breaks when } \\
\text { needed }\end{array}$ \\
\hline Tests & State standards & $\begin{array}{l}\text { Stress thermometer } \\
\text { Travel Card } \\
\text { In resource room }\end{array}$ & $\begin{array}{l}\text { Menu } \\
\text { (after } \\
\text { test) } \\
\text { Verbal }\end{array}$ & $\begin{array}{l}\text { Coping cards } \\
\text { Run errand before test } \\
\text { begins }\end{array}$ & Help card & $\begin{array}{l}\text { Grade book } \\
\text { Stress level (M, } \\
\mathrm{H} / \mathrm{M} / \mathrm{L}) \text { and } \\
\text { use of coping } \\
\text { cards (Y/N) }\end{array}$ & $\begin{array}{l}\text { Coping cards } \\
\text { throughout } \\
\text { day }\end{array}$ \\
\hline Lectures & $\begin{array}{l}\text { Partial note } \\
\text { taking, } \\
\text { attention to } \\
\text { task }\end{array}$ & $\begin{array}{l}\text { Stress thermometer } \\
\text { Homework checklist } \\
\text { Calendar of long-term } \\
\text { assignments } \\
\text { Copy of lecture notes } \\
\text { Travel Card }\end{array}$ & Verbal & Coping cards & Help card & $\begin{array}{l}\text { Complete notes } \\
(\%) \\
\text { Stress level (M, } \\
\text { H/M/L) and } \\
\text { use of coping } \\
\text { cards (Y/N) }\end{array}$ & $\begin{array}{l}\text { Coping cards } \\
\text { throughout } \\
\text { day }\end{array}$ \\
\hline Homework & $\begin{array}{l}\text { Completion, } \\
\text { turning in }\end{array}$ & $\begin{array}{l}\text { Stress thermometer } \\
\text { Travel Card } \\
\text { Calendar of long-term } \\
\text { assignment } \\
\text { Homework checklist }\end{array}$ & Verbal & $\begin{array}{l}\text { Coping cards } \\
\text { Break before and after } \\
\text { homework }\end{array}$ & & $\begin{array}{l}\text { Grade book } \\
\text { (accuracyl } \\
\text { turned in) }\end{array}$ & $\begin{array}{l}\text { Coping cards } \\
\text { throughout } \\
\text { day }\end{array}$ \\
\hline
\end{tabular}

Source: From The Comprehensive Autism Planning System (CAPS) for Individuals with Asperger Syndrome, Autism and Related Disabilities: Integrating Best Practices throughout the Student's Day, by S. A. Henry \& B. S. Myles, 2007. Shawnee Mission, KS: AAPC. Copyright 2007 by the AAPC. Reprinted with permission.

\section{FIGURE 11. Modified Comprehensive Autism Planning System: Reggie}

\begin{tabular}{|c|c|c|c|c|c|c|c|}
\hline$\frac{\substack{\frac{2}{3} \\
\frac{y}{4}}}{4}$ & 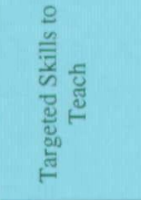 & 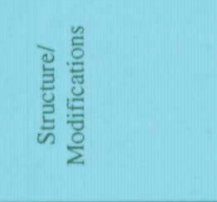 & 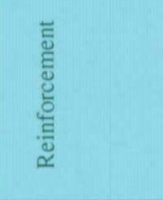 & 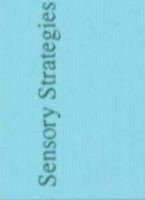 & 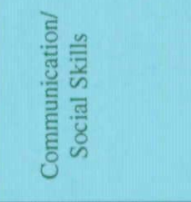 & 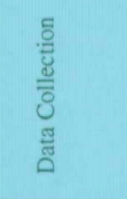 & 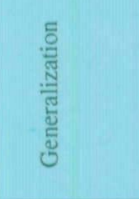 \\
\hline $\mathrm{PE}$ & $\begin{array}{l}\text { Participation } \\
\text { in group } \\
\text { sports } \\
\text { Accepting } \\
\text { loss }\end{array}$ & $\begin{array}{l}\text { Calendar of } \\
\text { competitive events } \\
\text { Run errands as } \\
\text { needed (behavior; } \\
\text { space invasion, loud } \\
\text { voice, when game } \\
\text { ends) } \\
\text { Review sportsman- } \\
\text { ship rules }\end{array}$ & $\begin{array}{l}\text { Social } \\
\text { reinforcer } \\
\text { Earns } 15 \\
\text { minutes on the } \\
\text { computer for } \\
\text { accepting loss } \\
\text { and } \\
\text { participating }\end{array}$ & $\begin{array}{l}\text { Ear plugs } \\
\text { Coping cards } \\
\text { Breaks }\end{array}$ & $\begin{array}{l}\text { Game statistician } \\
\text { Peer buddy } \\
\text { Social narrative } \\
\text { on accepting loss }\end{array}$ & $\begin{array}{l}\text { Time in PE } \\
\text { (M) } \\
\text { Number of } \\
\text { meltdowns } \\
\text { (daily) }\end{array}$ & $\begin{array}{l}\text { Accept loss } \\
\text { during } \\
\text { games in } \\
\text { Scouts }\end{array}$ \\
\hline Life Skills & $\begin{array}{l}\text { Self- } \\
\text { regulation }\end{array}$ & $\begin{array}{l}\text { ISA curriculum } \\
\text { ECLIPSE } \\
\text { curriculum }\end{array}$ & $\begin{array}{l}\text { Interactions } \\
\text { with peers } \\
\text { Verbal }\end{array}$ & $\begin{array}{l}\text { Sensory scan } \\
\text { (ISA) }\end{array}$ & $\begin{array}{l}\text { Social narrative } \\
\text { on accepting loss } \\
\text { Social scan (ISA) } \\
\text { Cartooning for } \\
\text { social challenges } \\
\text { Video modeling } \\
\text { on conversational } \\
\text { manners and } \\
\text { related skills }\end{array}$ & $\begin{array}{l}\text { Number of } \\
\text { meltdowns } \\
\text { ISA and } \\
\text { ECLIPSE } \\
\text { worksheets }\end{array}$ & $\begin{array}{l}\text { Social and } \\
\text { sensory scan } \\
\text { at home }\end{array}$ \\
\hline
\end{tabular}

Source: From The Comprehensive Autism Planning System (CAPS) for Individuals with Asperger Syndrome, Autism and Related Disabilities: Integrating Best Practices throughout the Student's Day, by S. A. Henry \& B. S. Myles, 2007. Shawnee Mission, KS: AAPC. Copyright 2007 by the AAPC. Reprinted with permission. 
Date

Key $\quad+=$ Yes $\quad 0=$ No $\quad$ NA $=$ Not Applicable

\begin{tabular}{|l|l|l|l|l|l|}
\hline & $\begin{array}{l}\text { Did student } \\
\text { bring supplies } \\
\text { to class? }\end{array}$ & $\begin{array}{l}\text { Did student } \\
\text { regulate his } \\
\text { behavior? }\end{array}$ & $\begin{array}{l}\text { Did student } \\
\text { complete } \\
\text { assignments? }\end{array}$ & $\begin{array}{l}\text { Did student } \\
\text { turn in } \\
\text { homework? }\end{array}$ & $\begin{array}{l}\text { Teacher's } \\
\text { initials }\end{array}$ \\
\hline Life Skills & & & & & \\
\hline PE & & & & & \\
\hline Government & & & & & \\
\hline Study Skills & & & & & \\
\hline English & & & & & \\
\hline Science & & & & & \\
\hline
\end{tabular}

\begin{tabular}{|l|l|l|l|}
\hline Bonus Points & $\begin{array}{l}\text { Did student talk about topics } \\
\text { other than sports? }\end{array}$ & $\begin{array}{l}\text { Has } \\
\text { assignment } \\
\text { book? }\end{array}$ & \\
\hline
\end{tabular}

\begin{tabular}{|l|l|l|}
\hline Total & + & 0 \\
\hline
\end{tabular}

\section{Teacher Comments/Suggestions/Announcements:}

Reggie will earn 5 baseball cards each week (at home) for $80 \%$ completion. At school, Reggie

earns 5 minutes on the computer for each 10 checks.

Source: From "The Travel Card," by L. Carpenter, 2002. In B. S. Myles \& D. Adreon (Eds.), Asperger Syndrome and Adolescence: Practical Solutions for School Success. Shawnee Mission, KS: AAPC. Copyright 2002 by the AAPC. Reprinted with permission.

\section{FIGURE 13. Sample Travel Card for Reggie}

\section{REFERENCES}

American Psychiatric Association (APA). (2010). DSM-5 development. Retrieved from http://www.dsm5.org

Angley, M., Semple, S., Hewton, C., Paterson, F., \& McKinnon, R. (2007) Children and autism: Part 2-Management with complementary medicines and dietary interventions. Australian Family Physician, 36(10), 827-830.

Angley, M., Young, R., Ellis, D., Chan, W., \& McKinnon, R. (2007). Children and autism: Part 1 - Recognition and pharmacological management. Australian Family Physician, 36(9), 741-744.

Aspy, R., \& Grossman, B. G. (2007). The Ziggurat model: A framework for designing comprehensive interventions for individuals with high-functioning autism and Asperger Syndrome. Shawnee Mission, KS: Autism Asperger.

Baranek, G. T. (2002). Efficacy of sensory and motor interventions for children with autism. Journal of Autism and Developmental Disorders, 32(5), 397-422.

Carpenter, L. (2002). The travel card. In B. S. Myles \& D. Adreon (Eds.), Asperger Syndrome and adolescence: Practical solutions for school success. Shawnee Mission, KS: AAPC.

Case-Smith, J., \& Arbesman, M. (2008). Evidence-based review on interventions for autism used in occupational therapy. The American Journal of Occupational Therapy, 62(4), 416-429.
Chan, J. M., Lang, R., Rispoli, M., O'Reilly, M., Sigafoos, J., \& Cole, H. (2009). Use of peer mediated interventions in the treatment of autism spectrum disorders: A systematic review. Research in Autism Spectrum Disorders, 3, 876-889.

Charlop-Christy, M. H., Kurtz, P. F., \& Casey, F. (1990). Using aberrant behaviors as reinforcers for autistic children. Journal of Applied Behavior Analysis, 23, 163-181.

Centers for Disease Control and Prevention (CDC). (2009). Prevalence of autism spectrum disorders. Autism and Developmental Disabilities Monitoring Network, United States, 2006, 58(SS-10), 1-10.

Centers for Medicare and Medicaid Services (CMS). (2010). Autism spectrum disorders: Final report on environmental scan. Washington, DC: Author.

Fixsen, D., Blasé, K., Horner, R., \& Sugai, C. (2009). Concept paper: Develop the capacity for scaling up the effective use of evidencebased programs in state departments of education. Unpublished document, University of North Carolina, Chapel Hill.

Harper, C. B., Symon, J. B. G., \& Frea, W. D. (2008). Recess is timein: Using peers to improve social skills of children with autism. Journal of Autism and Developmental Disorders, 38, 815-826.

Henry, S. A., \& Myles, B. S. (2007). The comprehensive autism planning systems (CAPS) for individuals with Asperger Syndrome, autism and related disabilities: Integrating best practices throughout the student's day. Shawnee Mission, KS: Autism Asperger. 
Horner, R. H., Carr, E. G., Strain, P. S., Todd, A. W., \& Reed, H. K. (2002). Problem behavior interventions for young children with autism: A research synthesis. Journal of Autism and Developmental Disorders, 32(5), 423-446.

Kogan, M. D., Blumberg, S. J., Schieve, L. A., Boyle, C. A., Perrin, J. M., Ghandour, R. M., ... van Dyck, P. (2009). Prevalence of parent-reported diagnosis of autism spectrum disorder among children in the US, 2007. Pediatrics, 124(5), 1395-1403.

National Autism Center (NAC). (2009). National standards report: Addressing the need for evidence-based practice guidelines for autism spectrum disorders. Randolph, MA: Author.

National Professional Development Center on Autism Spectrum Disorders (NPDC on ASD). (nd). Evidence based practice briefs. Retrieved from http://autismpdc.fpg.unc.edu/content/briefs

National Research Council (NRC). (2001). Educating children with autism. Washington, DC: National Academy Press.

Schopler, E. (1994). Behavioral priorities for autism and related developmental disorders. In E. Schopler \& G. B. Mesibov (Eds.), Behavioral issues in autism (pp. 55-75). New York: Plenum Press.
Wang, P., \& Spillane, A. (2009). Evidence-based social skills interventions for children with autism: A meta-analysis. Education and Training in Developmental Disabilities, 44(3), 318-342.

Wheeler, J. J., Baggett, B. A., Fox, J., \& Blevins, L. (2006). Treatment integrity: A review of intervention studies conducted with autism. Focus on Autism and Other Developmental Disabilities, 21. $45-55$.

Wigham, S., Robertson, J., Emerson, E., Hatton, C., Elliott, J., Mcintosh, B., ... Joyce, T. (2008). Reported goal setting and benefits of person centered planning for people with intellectual disabilities. Journal of Intellectual Disabilities, 12, 143-152.

Wing, L. (1981). Asperger's syndrome: A clinical account. Psycholog. ical Medicine, 11, 115-129.

Winter-Messiers, M. A. (2007). From tarantulas to toilet brushes: Understanding the special interest areas of children and youth with Asperger syndrome. Remedial and Special Education, 28, 140-152.

Zecavati, N., \& Spence, S. J. (2009). Neurometabolic disorders and dysfunction in autism spectrum disorders. Neurology and Neuroscience Reports, 9, 129-136. 